\title{
Pedaforumissa pohdittiin digitalisaation ja koronapandemian vaikutuksia opetukseen
}

\section{Syvälahti, Kati}

2020-10-26

Syvälahti , K 2020 , ' Pedaforumissa pohdittiin digitalisaation ja koronapandemian vaikutuksia opetukseen ' , Signum , Vuosikerta. 2020/52, Nro 3 , Sivut 15-18 . https://doi.org/10.25033/sig.99225

http://hdl.handle.net/10138/322872

https://doi.org/10.25033/sig.99225

cc_by_nc_sa

publishedVersion

Downloaded from Helda, University of Helsinki institutional repository.

This is an electronic reprint of the original article.

This reprint may differ from the original in pagination and typographic detail.

Please cite the original version. 


\section{Kati Syvälahti \\ PEDAFORUMISSA POHDITTIIN \\ DIGITALISAATION JA KORONAPANDEMIAN VAIKUTUKSIA OPETUKSEEN}

Elokuussa järjestettiin korkeakoulujen opetuksen kehittämisestä kiinnostuneille Pedaforum-päivät. Päivillä keskusteltiin korkeakouluopetuksen ajankohtaisista asioista sekä erityisesti koronan vaikutuksesta opetukseen. Miten esityksissä näkyi se, että korkeakoulujen opetus siirtyi keväällä nopealla aikataululla etäopetukseksi? Helsingin yliopiston kirjaston Markku Roinila, Kimmo Koskinen ja Kati Syvälahti olivat mukana omalla esityksellään. Kirjaston asiantuntijoiden on hyödyllistä olla mukana Pedaforumissa seuraamassa pedagogiikan uusia ilmiöitä.

T änä vuonna Pedaforum-seminaarin järjestäjinä toimivat Oulun yliopisto ja Oulun ammattikorkeakoulu. Koronapandemian takia nopealla aikataululla seminaari päätettiin järjestää verkkototeutuksena Zoomin kautta 20.-2I.8.2020. Seminaarin järjestäminen etänä mahdollisti ensimmäistä kertaa ilmaisen ja avoimen osallistumisen. Seminaarin keskeisiä teemoja olivat jatkuva oppiminen, digipedagogiikka ja oppimisanalytiikka. Pedaforumiin osallistui I 200 asiantuntijaa. Seminaarissa oli useita pääpuhujia, I 30 esitystä ja I68 esittäjää. Pääpuhujien esitykset ja esitysten tallenteet löytyvät verkosta (ks. lähteet ja liitteet).

\section{Ohjaus- ja digiosaamista}

Opetus- ja kulttuuriministeriön korkeakoulu- ja tiedepolitiikan osaston johtaja Birgitta Vuorinen kertoi esityksessään kaikkien Suomen korkeakoulujen yhteisestä Digivisio-hankkeesta (digivisio2030.fi), johon liittyy myös korkeakoulupedagogiikan kehittämi- nen ja tutkimus. Vuorisen mukaan tutkimusperustainen kehittäminen on kestävä lähestymistapa korkeakouluopetuksen kehittämiseen. Digivision tavoitteena on avata oppimisen kansalliset tietovarannot yksilön ja yhteiskunnan käyttöön sekä nostaa Suomi joustavaksi oppimisen mallimaaksi. Tulevaisuudessa opetuksessa korostuvat esimerkiksi tekoäly, ohjaus- ja digiosaaminen. Esityksessään Vuorinen suositteli tutustumaan Auli Toomin ja Kirsi Pyhältön kirjoittamaan selvitykseen korkeakoulupedagogiikan ja oh-

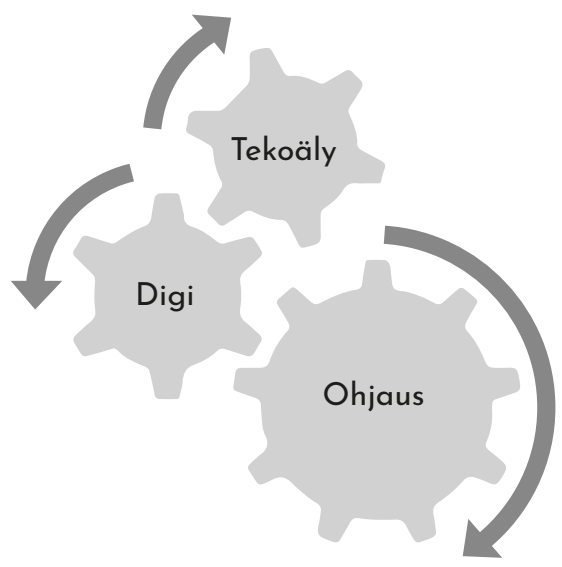

Tulevaisuuden opetuksessa korostuvat tekoäly, digi- ja ohjausosaaminen. 
jausosaamisen kehittämisestä (Toom ja Pyhältö 2020).

Vuorisen mukaan koronapandemia on myllertänyt korkeakouluopetusta ja paluuta täysin entiseen ei enää ole. Etäopetukseen siirtyminen nopealla aikataululla on kuormittanut sekä opettajia että opiskelijoita. Poikkeusoloissa selviytyäkseen tyypillinen tapa toimia on ollut monitekeminen eli multitasking. Vuorisen mukaan kaiken uuden tiedon jakamisen ja muutosten keskellä on tärkeää antaa opiskelijoille aikaa ajatella. Se on yksi keino edistää hyvinvointia ja jaksamista, kun on hetki aikaa oikeasti perehtyä ja syventyä asioihin.

Oulun yliopiston Oppimisen ja koulutusteknologian tutkimusyksikön johtaja Sanna Järvelä totesi esityksensä alussa, että Covid-I 9 ei ole ainoastaan terveyden kriisi vaan kysymys on myös oppimisen kriisistä. Järvelän mukaan opetus ja oppiminen on muuttumassa ja tulevaisuudessa tarvitaan uudenlaista osaamista. Järvelä pohti esityksessään, miten teknologian avulla voidaan tukea oppimisprosessin kriittisiä kohtia. Uudenlainen opetuskulttuuri korostaa Järvelän mukaan tieteidenvälisyyttä, yhteisöllistä oppimista, sosiaalisesti jaettua oppimisen säätelyä, edistynyttä oppimisen teknologiaa ja tekoälyä.

\section{Tutkimusperustainen} pedagogiikka

urun yliopiston korkeakoulupedagogiikan professori Mari Murtonen kertoi puheenvuorossaan tutkimusperustaisesta pedagogiikasta. Uusista kokeiluista ja innovaatioista on tärkeää tehdä tieteellistä tutkimusta, jotta ratkaisuja ei perusteta pelkkiin oletuksiin. Mari Murtonen kertoi esityksessään Tampereen korkeakouluyhteisössä toteutetusta kyselystä keväällä 2020. Kyselyyn vastasi 378 opetuksen ja ohjauksen parissa työskentelevää asiantuntijaa.

Tutkimuksessa tarkasteltiin, kuinka opettajat säätelevät omaa oppimistaan ja kehittymistään. Kyselyn tavoitteena oli saada tutkimustietoa siitä, kuinka pedagogiikan opinnot vaikuttavat opettajien tulkintoihin ja käsitykseen opetuksesta. Kyselyn vastauksissa kävi ilmi, että pedagogisella koulutuksella on positiivinen vaikutus opettajan näkemyksiin, opetustoimintaan ja muutoshalukkuuteen.

Koronatilanteen takia kyselyssä tiedusteltiin myös opetuksen muutoksiin liittyvistä negatiivisista ja positiivisista tunteista. Tekniset muutokset herättivät eniten positiivisia tunteita. Murtosen mukaan opettajien huolena oli pedagogiset ratkaisut, ei niinkään digitaidot- ja välineet.
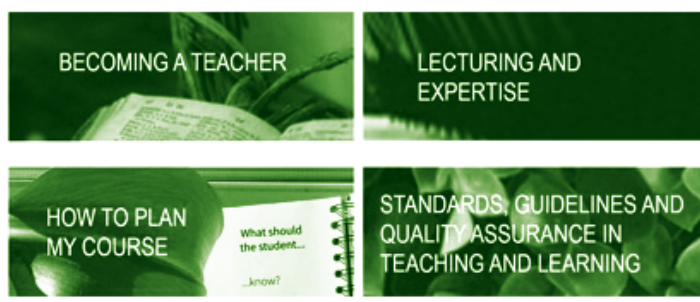

STANDARDS, CUIDELINES AND QUALIT ASSURANCE IN TEACHING AND LEARNING

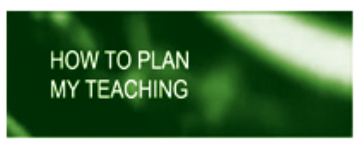

PEDAGOGIGS IN DIGITAL LEARNING

UNIPS-oppimisympäristössä (unips.fi) voi kehittää omaa pedagogista 
Murtonen kertoi esityksessään, että kaikille korkeakoulupedagogiikasta kiinnostuneille on tarjolla avoin itseopiskelumateriaali verkossa. UNIPS-oppimisympäristön (unips. fi) toteutukseen on osallistunut useita korkeakouluja. Materiaalia suositellaan erityisesti opetustyötä aloitteleville noviiseille opettajille.

\section{Etäopiskelua poikkeusoloissa}

Tia Rahkila Oulun yliopiston ylioppilaskunnasta ja Sami Luukela Oulun ammattikorkeakoulun opiskelijakunnasta kertoivat puheenvuorossaan, kuinka kevään poikkeustilanne on vaikuttanut opiskeluun. oyy:n kyselyyn vastanneista yli puolet koki, että heidän oli ollut mahdollista edistää opintojaan poikkeustilanteessa. Opiskelijat kokivat, että tiedonkulku oli toiminut hyvin. Suurin osa kyselyyn vastanneista opiskelijoista arvioi kuitenkin, että etäopiskeluun siirtyminen oli ollut kuormittavaa. Esimerkiksi opiskelumateriaalien saatavuus oli koettu haasteellisena.

OAMK:n opiskelijoiden mielestä etäopiskeluun siirtymisessä onnistuttiin, mutta opetuksen laadun koettiin muuttuneen huonommaksi. Opettajia oli ollut vaikea saada kiinni, tehtäviä tehtiin itsenäisesti, kursseja ja luentoja peruttiin. Harjoittelujen peru- minen myös viivästytti opiskelijoiden opintoja.

\section{Hyviä käytänteitä}

ouluttaja Mira Perämä-
ki (Mediamaisteri Oy) jakoi
virtuaalikahvilassa ideoita verkkokursseille. Hänen mukaan pedagogisesti hyvä verkkokurssi ei ole pelkkä materiaalien jakamisen paikka. Verkkokurssilla opettajan persoonan on tärkeää tulla näkyviin. Opettajan tehtävänä on luoda yhteisöllisyyttä kurssille esimerkiksi lyhyiden videotervehdysten avulla.

Poikkeusolojen etäopetuksen kokemusten jälkeen seminaarissa jaettiin paljon vinkkejä Zoomin käytöstä. Opettajille ja opiskelijoille kameran käyttö on vaatinut totuttelua ja harjoittelua uudenlaiseen vuorovaikutukseen. Rinnakkaissessiossa osallistujat pohtivat myös mikrofonin käyttöä ja tietokoneen mikrofonin koettiin olevan harvoin paras vaihtoehto. Lisäksi mahdollisimman vakaa verkkoyhteys on onnistuneen etäopetuksen edellytys.

Projektipäällikkö Anna Lindfors CSc:ltä kertoi seminaarissa Avointen oppimateriaalien kirjastosta (aoe.fi). Palveluun voi tallentaa ja kuvailla kaikille avoimia oppimateriaaleja, jotka lisensoidaan Creative Commons -lisenssillä.

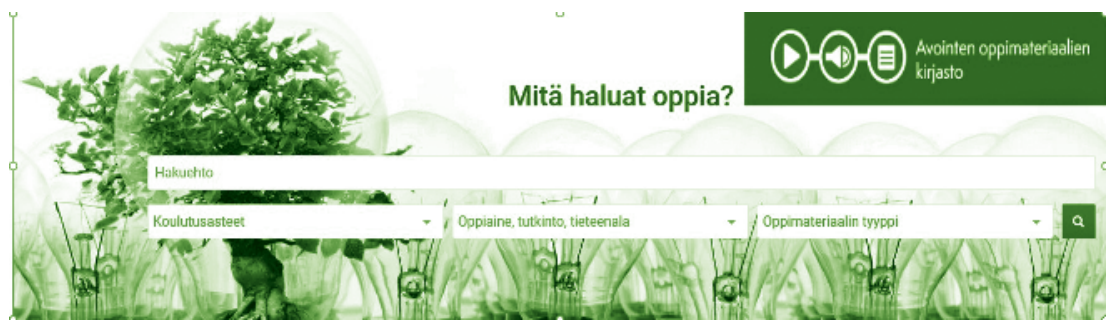


Oulun ammattikorkeakoulun Pia Partasen ja Oulun yliopiston Heli Huttusen esityksen aiheena oli vuoden 2019 aikana lukivaikeuksisille opiskelijoille järjestetty DigiTools-ryhmä. Työpajojen tavoitteena oli madaltaa digitaalisten sovellusten käyttöönottoa. Opiskelijoiden ja ohjaajien kokemukset ryhmätoiminnasta olivat myönteisiä. Digitools-ryhmät oli koettu käytännönläheiseksi ja erityisesti vertaistuen opiskelijat kokivat merkittäväksi asiaksi.

Helsingin yliopiston kirjaston Markku Roinilan, Kimmo Koskisen ja Kati Syvälahden esityksen aiheena oli Editori-palvelu, joka toimii Open Journals Systems (oJs) julkaisualustalla (journals.helsinki.fi). Editorin avulla voi harjoitella avointa julkaisemista ja julkaisukäytänteitä. Esityksessä kerrottiin pilottiprojektista, jossa Editoria käytettiin Helsingin yliopiston filosofian, taiteiden ja yhteiskunnan tutkimuksen tohtoriohjelman kurssilla. Opettajat ja opiskelijat kokivat Editorin hyödylliseksi ja toimivaksi.

\section{Lopuksi}

Poikkeusolojen jatkuessa opettajien ja opiskelijoiden on tärkeää jakaa keskenään hyviä käytänteitä, ideoita ja oivalluksia. Hyviksi koetut digipedagogiset ratkaisut ovat arvokkaita asioita opetustyön arjessa. Toisaalta poikkeusolojen aikana on tärkeää kiinnittää erityistä huomiota opiskelijoiden ja korkeakoulujen henkilökunnan jaksamiseen ja hyvinvointiin. Seuraavan Pedaforumin järjestää Haaga-Helia-ammattikorkeakoulu vuonna 2022.

Tämän artikkelin ideoinnista haluan esittää kiitoksen Helsingin yliopiston kirjaston pedaryhmälle.

\section{Lähteet ja linkit:}

Avoimien oppimateriaalien kirjasto. https://aoe.fi

Editori - Helsingin yliopiston avoimen julkaisemisen palvelu. https://journals.helsinki.fi/

Korkeakoulutuksen digivisio 2030. https://digivisio2030.fi/

Partanen, P. \& Huttunen, H. 2020. DigiTools-rules! -

Digitaaliset sovellukset opiskelun ja oppimisen tukena.

https://read.bookcreator.com/W22KLaQxnQcbjyotie29lVVo6o32/oXriue7YRjy5vqzix7ZskA

Pedaforum 2020 pääpuhujien esitykset ja esitysten tallenteet.

https://www.oulu.fi/pedaforum2020/ohjelma

Тоом, А. \& Рүнӓцтӧ, K. 2020. Kestävää korkeakoulutusta ja opiskelijoiden oppimista rakentamassa: Tutkimukseen perustuva selvitys ajankohtaisesta korkeakoulupedagogiikan ja ohjauksen osaamisesta. Helsinki: Opetus- ja kulttuuriministeriö. Saatavilla: http://urn.fi/URN:ISBN:978-952-263-696-6

UNıPS. Avoin digitaalinen yliopistopedagogiikan itseopiskelumateriaali. https://unips.fi/

\section{Tietoa kirjoittajasta}

KaTI SyväLAHTI

Helsingin yliopiston kirjasto

kati.syvalahti@helsinki.fi 